OPEN ACCESS

Edited by:

Sibao Wang,

Shanghai Institutes for Biological Sciences (CAS), China

Reviewed by:

Mika Tapio Tarkka, Helmholtz Centre for Environmental Research (UFZ), Germany

Ram Prasad,

Amity University, India

*Correspondence:

Cândida Lucas

clucas@bio.uminho.pt

Specialty section: This article was submitted to Fungi and Their Interactions, a section of the journal

Frontiers in Microbiology

Received: 07 March 2019 Accepted: 17 July 2019

Published: 31 July 2019

Citation:

Ferraz P, Cássio F and Lucas $C$

(2019) Potential of Yeasts as

Biocontrol Agents of the

Phytopathogen Causing Cacao Witches' Broom Disease: Is Microbial

Warfare a Solution?

Front. Microbiol. 10:1766. doi: 10.3389/fmicb.2019.01766

\section{Potential of Yeasts as Biocontrol Agents of the Phytopathogen Causing Cacao Witches' Broom Disease: Is Microbial Warfare a Solution?}

\author{
Pedro Ferraz ${ }^{1,2}$, Fernanda Cássio ${ }^{1,2}$ and Cândida Lucas ${ }^{1,2 *}$ \\ ${ }^{1}$ Institute of Science and Innovation for Bio-Sustainability, University of Minho, Braga, Portugal, ${ }^{2}$ Centre of Molecular \\ and Environmental Biology, University of Minho, Braga, Portugal
}

Plant diseases caused by fungal pathogens are responsible for major crop losses worldwide, with a significant socio-economic impact on the life of millions of people who depend on agriculture-exclusive economy. This is the case of the Witches' Broom Disease (WBD) affecting cacao plant and fruit in South and Central America. The severity and extent of this disease is prospected to impact the growing global chocolate market in a few decades. WBD is caused by the basidiomycete fungus Moniliophthora perniciosa. The methods used to contain the fungus mainly rely on chemical fungicides, such as copper-based compounds or azoles. Not only are these highly ineffective, but also their utilization is increasingly restricted by the cacao industry, in part because it promotes fungal resistance, in part related to consumers' health concerns and environmental awareness. Therefore, the disease is being currently tentatively controlled through phytosanitary pruning, although the full removal of infected plant material is impossible and the fungus maintains persistent inoculum in the soil, or using an endophytic fungal parasite of Moniliophthora perniciosa which production is not sustainable. The growth of Moniliophthora perniciosa was reported as being antagonized in vitro by some yeasts, which suggests that they could be used as biological control agents, suppressing the fungus multiplication and containing its spread. Concurrently, some yeast-based products are used in the protection of fruits from postharvest fungal spoilage, and the extension of diverse food products shelf-life. These successful applications suggest that yeasts can be regarded a serious alternative also in the pre-harvest management of WBD and other fungal plant diseases. Yeasts' GRAS (Generally Recognized as Safe) nature adds to their appropriateness for field application, not raising major ecological concerns as do the present more aggressive 
approaches. Importantly, mitigating WBD, in a sustainable manner, would predictably have a high socioeconomic impact, contributing to diminish poverty in the cacaoproducing rural communities severely affected by the disease. This review discusses the importance/advantages and the challenges that such a strategy would have for WBD containment, and presents the available information on the molecular and cellular mechanisms underlying fungi antagonism by yeasts.

Keywords: Witches' Broom Disease, Moniliophthora perniciosa, yeasts, biocide, antagonism, sustainability, cacao, phytopathogen

\section{INTRODUCTION}

A great number of plant diseases are responsible for major crop losses with huge socio-economic impact, causing each year a worldwide estimated losses of 40 billion dollars (Syed Ab Rahman et al., 2018). Particularly, the diseases caused by fungal pathogens are increasingly recognized as a global threat to food production and security. In fact, since 2000 the number of new fungal plant pathogen alerts has increased by more than sevenfold (Fisher et al., 2012). Presently, fungal-generated diseases constitute 64$67 \%$ of the total crop diseases reported globally (Fisher et al., 2012; Fisher et al., 2018), and account for $20 \%$ of the losses at the level of production and a further $10 \%$ at postharvest level (Fisher et al., 2018). These authors estimate that fungal diseases are spreading northbound at a rate of almost $8 \mathrm{~km} /$ year. This could derive from increasingly common agricultural practices, such as the extensive monocultures and the use of a restricted number of plant cultivars, as well as the increased global international trade proportionating disease spreading over great distances (Fisher et al., 2012). Climate change adds a burden to that equation, potentiating the development of microbes and vectors in unprecedented regions (Robert et al., 2015; Fisher et al., 2018).

To prevent plant diseases and protect crops from pests and pathogens, widely spread methodologies mainly correspond to applying chemical fungicides. The continued use of chemical fungicides leads to the development of fungicide resistance in the fungal pathogen (Syed Ab Rahman et al., 2018) and, in the absence of other control measures, to the re-emergence of virulence (Fisher et al., 2018). Therefore, in spite that the use of pesticides brought clear improvements in crop quality and quantity during more than half a century, their progressive inefficacy to treat some of the most harmful plant diseases requires the utilization of higher dosages each year (Medeiros et al., 2010; Syed Ab Rahman et al., 2018). The use of fungicides heavily impacts on the microflora of agrarian ecosystems, destroying beneficial microbes, such as endophytic bacteria and fungi, as well as animals important for the quality of the soils (Syed Ab Rahman et al., 2018). Ultimately, the systemic use of these drugs leads to the persistence of chemical residues in the environment, proportionating low dosage toxicity and contaminating species across trophic levels (Carvalho, 2006; Dukare et al., 2018).

One of the fungal diseases with recognized high negative socio-economic impact is the pathology of cacao plant and fruit known as Witches' Broom Disease (WBD). This is caused by the basidiomycete fungus Moniliophthora perniciosa (Aime and
Phillips-Mora, 2005) (formerly designated Crinipellis perniciosa). The severity and extent of its manifestation is endangering the rapidly expanding and very quality-demanding chocolate market. This review focuses on this disease, the methodologies presently used for containment, and the innovative approaches that could be explored (Figure 1).

\section{WITCHES' BROOM DISEASE OF CACAO}

According to data from the International Cacao Organization ${ }^{1}$, more than 4 million tons of cacao beans are produced annually (Wickramasuriya and Dunwell, 2018). Cacao beans are the core raw material for the chocolate industry, although other cacaoderived products also have important world markets, such as cacao butter or liquor (Pohlan and Pérez, 2010; Wickramasuriya and Dunwell, 2018). The economic global market for chocolate reached US\$ 110 billion in 2015, and the world demand is expected to grow exponentially in the next decade due to the globalization of consumption styles in expanding economies such as China and India (Squicciarini and Swinnen, 2016). Cacao is produced in countries located approximately in the same latitude interval of equatorial climate, forming the so-called Cacao Belt (Pohlan and Pérez, 2010). The biggest producers are therefore countries from Central and South America and Africa. The cacao plant is affected by several diseases, the more threatening of which is WBD (Purdy and Schmidt, 1996; Pereira, 1999; Griffith et al., 2003; Aime and Phillips-Mora, 2005; Teixeira et al., 2015). This has severely affected South and Central America countries, where it has been responsible for major irreversible crop losses. The highest economic and social consequences of WBD are described to have occurred in Brazil. In the 10 years after the onset of the disease in 1989, WBD reduced the cacao production in more than 70\% (Pereira et al., 1989; Santos Filho et al., 1998; Trevizan and Marques, 2002; Meinhardt et al., 2008; Pires et al., 2009; Teixeira et al., 2015), causing Brazil to shift from being the 2nd world producer to becoming a net importer of cacao beans (Bowers et al., 2001; Marelli et al., 2009; Teixeira et al., 2015). During that period, the most affected region of Bahia suffered losses around 90\%, configuring a severe social crisis from losing more than 200,000 farm jobs (Trevizan and Marques, 2002; Teixeira et al., 2015).

The severity of WBD derives from several factors. Moniliophthora perniciosa does not form specialized infection

\footnotetext{
${ }^{1}$ www.ICCO.org
} 




\section{CHALLENGES}

\section{OPPORTUNITIES}

high autochtonous microbial biodiversity

availability of natural $M$. perniciosa microbial antagonists that: are unharmful to man are unharmful to the plant do not disturb the food chains do not pollute water do not affect the environment in the long-run

are amenable and cheap to reproduce local populations are familiar with, ensuring sustainability

FIGURE 1 | Diagram presenting the challenges posed by WBD and the opportunities that natural antagonistic yeasts present for the containment of the disease. Cacao plant figure adapted from Panhuys, L. von, Watercolours of Surinam (1811-1824) (source: (CC) BY-NC-ND http://plantillustrations. org/illustration.php?id_illustration=190533).

structures such as appressoria like other fungal pathogens. Since it is a hemibiotrophic fungus, the full infectious cycle unfolds through two distinct phases: (i) biotrophic and (ii) saprotrophic. (i) The initial infection occurs in young meristematic tissues and susceptible actively growing tissues (e.g., buds, young leaves, flower cushions, young fruits). The fungus penetrates through the stomatal openings, the bases of damaged trichomes and the husk of young fruits (Aime and Phillips-Mora, 2005). After the initial infection, the fungus induces hypertrophy and hyperplasia, causing the loss of apical dominance. This corresponds to a disorganized proliferation of the infected vegetative meristems of axillary shoots that results in the formation of a broomlike structure of abnormal stems called a green broom (Aime and Phillips-Mora, 2005; Meinhardt et al., 2008; Pires et al., 2009). Shortly after the initial infection, the fungus starts growing intercellularly, forming a monokaryotic and parasitic mycelium without clamp connections, establishing a biotrophic relationship with the host that corresponds to its life cycle biotrophic phase. (ii) Usually 4-6 weeks after the development of the green brooms, a concerted series of infected plant cells death events occurs and the infected tissues become necrotic forming a structure called dry broom. Necrotic or dead host cells are then colonized by the fungus (Evans, 1980; Meinhardt et al., 2008), which at this point, suffers major morphological changes entering its saprotrophic phase (Lawrence et al., 1991; Meinhardt et al., 2008). The hyphae become dikaryotic, clamp connections are formed, and the fungus begins to grow intracellularly, as well as between cells. The exact mechanisms and signaling factors that trigger the switch from the biotrophic phase to a saprotrophic phase, controlling the developmental alterations, remain unknown (Meinhardt et al., 2008). After the fungus proliferation and colonization of the dead host tissues, pink colored basidiocarps (small mushrooms) are produced on any infected necrotic tissue. Upon alternate wet and dry periods, each basidiocarp can produce 2-3.5 million spores (basidiospores), this way completing the fungus life cycle (Rocha and Wheeler, 1985; Almeida et al., 1997). The release of the spores occurs mainly at night, and is related to a high level of humidity and favorable temperature $\left(20-30^{\circ} \mathrm{C}\right)$. The spores are disseminated locally by water and over long distances by wind, and can endure latent in the soil or inside pruned branches of the plants for long periods (Meinhardt et al., 2008; Pohlan and Pérez, 2010). The ability of Moniliophthora perniciosa to infect the plant in all stages of its life-cycle and the fact that virtually all the plant tissues can be infected, underlie this pest exceptional virulence. This, allied to the fungus high prevalence in the soil and plant dead material, explains why once a single plant develops symptoms the whole plantation can be compromised.

The resilience of Moniliophthora perniciosa relies essentially on its capacity to colonize both alive and dead plant tissue, the biotrophic and necrotrophic life cycle phases above mentioned. The shift between the two phases involves a drastic morphological and life style change. Alternative Oxidase (AOXp)-respiration was associated with this transition (Thomazella et al., 2012). Possibly, this type of respiration allows the fungal cell to overcome the plant host defenses generated in the first stages of the WBD, as observed with better studied model fungus Ustilago maydis (Cárdenas-Monroy et al., 2017). The plant defenses include the production of high amounts of $\mathrm{NO}$, which affect the fungal mitochondria, namely inhibiting respiration complex IV, this way inducing the production of ROS (Thomazella et al., 2012). AOXp is an alternative mitochondrial oxidase that constitutes alone a bypass to respiratory chain complexes III and IV, which function prevents collapse from drugs that target these complexes like cyanide or Antimycin-A (Maxwell et al., 1999; Ruy et al., 2006; Vanlerberghe et al., 2009). At the same time, AOXp-respiration contributes to cope with the electron flux overflow without phosphorylation, and therefore without producing ATP (Van Aken et al., 2009) lowering the global energy yield of metabolism. AOX-encoding gene sequences are found in many organisms (including yeasts and fungi) (Elthon and McIntosh, 1987; Joseph-Horne et al., 2001; Stenmark and Nordlund, 2003; Chaudhuri et al., 2006; McDonald et al., 2009), but their physiological role in microbes is still not very well understood (Veiga et al., 2003; Rogov and Zvyagilskaya, 2015). In the case of Moniliophthora perniciosa, AOXp activity 
would prevent excessive ROS accumulation inside the fungal cell induced by the host, while maintaining a low metabolism status (Thomazella et al., 2012), which could explain how the fungal cell stays alive while the plant weakens.

In spite of the few Moniliophthora perniciosa genome surveys in the attempt to identify proteins/genes involved in this fungus infectious behavior (e.g., Mondego et al., 2008; Rincones et al., 2008), in fact little is known on this fungus molecular biology, mostly because as all non-model organisms it lacks the appropriate tools for genetic manipulation. Still, some physiological traits apart from AOX-respiration were shown in connection to this fungus pathosystem, like the increased secretion by the host of malondialdehyde (MDA) (usually a marker of oxidative stress; Del Rio et al., 2005) and glycerol (Scarpari et al., 2005), as well as of a methanol oxidase (MOX) (de Oliveira et al., 2012). Additionally, as for other fungal infections, also in this case the levels of the plant growth hormone ethylene are hypothesized to have a crucial role in the progression of the WBD, in particular in the development of the broom (Scarpari et al., 2005). The biological meaning of these findings remains unknown.

\section{WITCHES' BROOM DISEASE MANAGEMENT}

The chemical fungicides generally used are either copperbased compounds, such as cuprous oxide, or azole-containing molecules, particularly tebuconazole (Oliveira and Luz, 2005; Medeiros et al., 2010). These are usually used to control the spread of other fungal plant diseases such as grapevine downy mildew and olive peacock spot, but showed very low efficiency against Moniliophthora perniciosa (Medeiros et al., 2010). Copper is per se a non-specific anti-microbial agent able to destroy naturally occurring microorganisms, including fungi, that is for decades applied as foliar sprays (Yang et al., 2011; Husak, 2015). The lethal action of copper-based fungicides derives from their ability to free copper ions that are massively internalized by the fungal cells. Intracellularly, they bind various chemical groups (imidazoles, phosphates, sulfhydryls, hydroxyls) namely in proteins, causing their denaturation and loss of function (Husak, 2015; Mirković et al., 2015). Ultimately, this leads to irreversible cell damage and membrane leakage (Husak, 2015). Yet some fungi are resistant to copper ions. The mechanisms underlying this resistance are not well understood, although several studies have suggested that they might exert a combined action: the extracellular chelation and cell wall sequester of copper ions, and their decreased intake and intracellular complexing by metallothioneins or other proteins (Cervantes and GutierrezCorona, 1994). This last case includes the over-expression of the superoxide dismutase (SOD) that uses copper as inorganic co-factor (Naiki, 1980). SOD has been described to display the ability to buffer copper excess independently of its superoxide scavenging function (Culotta et al., 1995). Additionally, the copper-induced accumulation of glycerol was also described to be involved in its extrusion (Gadd et al., 1984). Neither of these mechanisms were ever described in association with Moniliophthora perniciosa, although increased levels of SOD would contribute the higher resistance to the above-mentioned plant-generated ROS.

On the other hand, tebuconazole, as other azole-fungicides, acts on the synthesis of ergosterol, altering the structure and functionality of the fungal cell membrane (Price et al., 2015) as well as vacuolar ion homeostasis through v-ATPase function (Zhang V. Q. et al., 2010). In consequence of ergosterol synthesis disruption, mitochondrial function is also affected in its ability to form iron-sulfur clusters, which results in the deposit of insoluble iron inside mitochondria and concomitant radical formation and mitochondrial loss (Ward et al., 2018). CytC harbors a heme group which availability for this enzyme proper assembly and function would be affected by iron homeostasis disruption, consequently affecting Complex IV function in respiration. This would justify why fungi that can respire through the AOXp could be resistant to azoles. Still, there is no reference to this possibility in the literature. Rather, in Candida species, the resistance to azole-fungicides implicates other types of mechanisms (Whaley et al., 2017). Nevertheless, these are human commensals and pathogens, having therefore specificities that are not common with other yeasts or fungi.

Fungicides fail to control the spread of the WBD but the mechanisms underlying the resistance of Moniliophthora perniciosa to these drugs are not studied. The use of fungicides is therefore not a routine practice in most cacao-producing countries also due to their high cost, and the risks associated with cacao chemical contamination which hinders commercialization. The reasons underlying this include the increasingly considered negative impact of fungicides on human health and the environment. Public concerns regarding the prevalence of agronomic pesticide residues in food, and their relation with the increasing advent of pesticide resistant pathogens, not only in plants but also in humans (Droby, 2006; Pal and McSpadden Gardener, 2006; Marelli et al., 2009; Verweij et al., 2009; Nunes, 2012) led to restrictions in Europe. Therefore, the most commonly used methods to control the WBD are exclusively agronomic, through phytosanitary pruning, removing as much as possible the infected material, which is though often impossible, due to hidden fungal inoculum in the soil and cut branches and leaves $^{2}$. Therefore, more effective and eco-friendly methods and strategies are needed to satisfy the consumer demands.

A concept that has gained considerable prominence in the agriculture sector in recent years is the use of nanoagroparticles, which are nanoparticles designed to mitigate agriculture-related problems, including plant pathologies (Parizi et al., 2014; Parisi et al., 2015). These nanoagroparticles include silver, copper, sulfur, zinc oxide and magnesium oxide nanoparticles (Baker et al., 2017), and can act efficiently as fungicides, pesticides, herbicides and also insecticides. They can easily enter into the fungal cell wall. Once inside the cell, they act through different modes, which include (i) causing the disruption of metabolism, or of the cell membrane, with consequent loss of

${ }^{2}$ Available at: https://www.icco.org/about-cocoa/pest-a-diseases.html (accessed February 18, 2019). 
cellular content (Baker et al., 2015, 2017), (ii) promoting the release of toxic ions $\left(\mathrm{Cd}^{2+}, \mathrm{Zn}^{2+}\right.$, and $\left.\mathrm{Ag}^{+}\right)$that bind to sulfurcontaining proteins, (iii) targeting the pathogen DNA, this way inducing cell death, (iv) interrupting electron transport, this way causing the collapse of membrane potential, (v) promoting the generation of ROS, or (vi) interfering with nutrient uptake (Alghuthaymi et al., 2015). More than one of these mechanisms can occur simultaneously, conferring the ability of nanoparticles to be effective against different plant pathogens (Alghuthaymi et al., 2015). Recently, nanoparticles were conjugated with some biomolecules (including biocide/killer toxins), forming bionanohybrid agroparticles (Baker et al., 2017). The free utilization of these promising phytopathology management tools still requires not only cytotoxicology studies to evaluate potential harm to human and animal health, but even more important, extensive ecotoxicology and biodegradability studies to evaluate their prevalence in the environment and food chains and their effect on the long run in the microflora of plant, soil and water. Presently few information on this regard is available (Alghuthaymi et al., 2015). Nonetheless, the prospective of being able to use such a nanotool to effectively deliver a toxin and kill a phytopathogenic fungus is attractive, especially if carrying a bio-derived killing agent.

\section{YEASTS AS BIOCONTROL AGENTS}

One possible approach to fungal diseases in plants might be the use of biocides or biological control agents. In phytopathology, this term designates the use of introduced or resident living organisms to contain or suppress populations of pathogens (Pal and McSpadden Gardener, 2006). There are a few of these agents in the market, mostly used in the control of pests at small scale. They correspond to dry biomass of bacterial or filamentous fungal strains isolated from the endosphere or the rhizosphere of plants (O'Brien, 2017) that are re-hydrated and used as alive reproductive microorganisms. These include a taxonomically and biologically diverse group of endophytic fungi that are characterized by colonizing internally the plant host tissues without causing any external disease symptoms (Wilson, 1995; Rubini et al., 2005). These endophytes can prevent pathogen infection and propagation directly by competition, mycoparasitism or antibiosis, or indirectly by inducing resistance responses in the plant (Bailey et al., 2006). Despite this, the biocontrol agents that could be applied in phytopathology are not restricted to these two groups of organisms.

Endophytic microorganisms also include Ascomycota and Basidiomycota yeasts, found in many species of trees from very diverse climates, but also in agricultural species (reviewed by Doty, 2013). Ascomycota yeasts reproduce exclusively by budding, as the most well-known yeast Saccharomyces cerevisiae. Basidiomycota grow dimorphically, shifting from a monokaryotic yeast-form to a dikaryotic filamentous form (Choudhary and Johri, 2009). This is the case of Rhodotorula and Cryptococcus sp. (Table 1). Generally, endophytic yeasts apparently thrive symbiotically or mutualistically, virtually colonizing diverse plant tissues (reviewed by Doty, 2013), in which they may cause structural changes (Luna, 2017). They consume sugars and assimilate amino acids generated by the plant, and contribute to the plant wellbeing and stress response in many different ways, including the production of phytopheromones, catalase or siderophores (reviewed by Joubert and Doty, 2018). Importantly, endophytic like epiphytic yeasts can antagonize phytopathogenic filamentous fungi, either by occupying their niche or by antagonizing them in more complex ways.

The antagonistic interaction of yeasts with particular phytopathogenic fungi has been described in the literature. For example, Suzzi et al. (1995) observed that natural wine yeast strains of Saccharomyces and Zygosaccharomyces inhibited in vitro the growth of 10 species of soil-borne fungal plant pathogens, namely Cladosporium variabile, Rhizoctonia fragariae, Phomopsis longicolla, Colletotrichum acutatum, Aspergillus niger, Sclerotinia sclerotiorum, Penicillium digitatum, Macrophomina phaseolina, Trichoderma viride, and Botrytis squamosa. Also, Walker et al. (1995) reported that strains of Saccharomyces cerevisiae and Pichia anomala (know designated Wickerhamomyces anomalus) inhibited in vitro the growth of several wood decay basidiomycetes including Serpula lacrymans, Postia placenta, Lentinus lepideus and Ophiostoma ulmi and phytopathogenic fungi, such as Rhizoctonia solani, Fusarium equiseti, Botrytis fabae, and Phytophthora infestans. Importantly, Rosa-Magri et al. (2011) described the antagonism effect of the yeast Torulaspora globosa against the phytopathogenic mold Colletotrichum graminicola, the causal agent of anthracnose disease in maize. All of these cases were reported as in vitro studies, none were performed in planta or in field. Otherwise, yeasts have often been proposed and used for the control of microbial contaminations at the postharvest phase (Table 1).

The possibility of using yeasts as biocontrol agents of fungal or bacterial proliferation associated with food spoilage has been recognized since the early 1960s, when it was found that Saccharomyces cerevisiae strains secreted toxins that killed other yeast strains but are immune to their own toxin (Bevan and Makower, 1963). Killer toxins (KTs) can be encoded by cytoplasm-inherited double-stranded RNA viruses (Schmitt and Breinig, 2002) or linear dsDNA plasmids (Schaffrath and Meinhardt, 2005), but they can also be chromosomally encoded (Suzuki, 2005). The killer phenomenon is well characterized and studied in Saccharomyces cerevisiae. In this yeast species, KTs have been grouped into four types, K1, K2, K28, and Klus, based on their killing profiles and lack of cross-immunity (Schmitt and Breinig, 2006; Rodríguez-Cousiño et al., 2011). Each strain producing one specific toxin kills strains from the other groups but has self-protective immunity (Schmitt and Breinig, 2006).

The modes of action of the Saccharomyces cerevisiae KTs are well known, with the exception of the recently found Klus toxin (Schmitt and Breinig, 2002). K1 and K2 toxins kill sensitive yeast cells in a receptor-mediated two-step process. The first step involves a fast, energy-independent binding to a primary toxin receptor (R1), consisting of $\beta$-1,6-D-glucan (Lukša et al., 2015). Though a second energy-dependent step, the toxin is translocated from the cell wall to the plasma membrane, where it interacts with a secondary membrane 
TABLE 1 | Success cases of using yeasts to antagonize the spoilage of fruits by filamentous fungi.

\begin{tabular}{|c|c|c|c|}
\hline Yeast antagonist & Host & Fungal phytopathogen(s) & References \\
\hline \multicolumn{4}{|l|}{ Preharvest application ${ }^{1}$} \\
\hline Candida (Pichia) guilliermondii & Cherry tomato & Fruit decay agents & Zhao et al., 2011 \\
\hline Candida sake & Apple & Penicillium expansum & Teixidó et al., 1999 \\
\hline \multicolumn{4}{|l|}{ Postharvest application } \\
\hline \multirow[t]{2}{*}{ Aureobasidium pullulans } & Pear & Penicillium expansum & Robiglio et al., 2011 \\
\hline & Apple & $\begin{array}{l}\text { Botrytis cinerea, Colletotrichum } \\
\text { acutatum and Penicillium } \\
\text { expansum }\end{array}$ & Mari et al., 2012 \\
\hline \multirow[t]{5}{*}{ Candida (Pichia) guilliermondii } & Chili & Colletotrichum capsici & Chanchaichaovivat et al., 2007 \\
\hline & Tomato & Rhizopus nigricans & Zhao et al., 2008 \\
\hline & & Rhizopus stolonifer & Celis et al., 2014 \\
\hline & Kiwifruit & Botrytis cinerea & Sui and Liu, 2014 \\
\hline & Papaya & Colletotrichum gloeosporioides & Lima et al., 2013 \\
\hline \multirow[t]{2}{*}{ Candida oleophila } & Banana & $\begin{array}{l}\text { Colletotrichum musae, } \\
\text { Fusarium moniliforme and } \\
\text { Cephalosporium sp. }\end{array}$ & Lassois et al., 2008 \\
\hline & Apple & $\begin{array}{l}\text { Penicillium expansum and } \\
\text { Botrytis cinerea }\end{array}$ & Liu et al., 2012 \\
\hline Candida pelliculosa & Tomato & Botrytis cinerea & Dal Bello et al., 2008 \\
\hline Candida sake & Apple & Penicillium expansum & Morales et al., 2008 \\
\hline Cryptococcus infirmominiatus & Sweet cherry & Monilinia fructicola & Spotts et al., 2002 \\
\hline \multirow[t]{2}{*}{ Cryptococcus laurentii } & Strawberry & Botrytis cinerea & Wei et al., 2014 \\
\hline & Sweet cherry & Fruit decay agents & Tian et al., 2004 \\
\hline \multirow[t]{2}{*}{ Debaryomyces hansenii } & Peach & Rhizopus stolonifer & Mandal et al., 2007 \\
\hline & Mandarin, orange & Penicillium digitatum & Taqarort et al., 2008 \\
\hline \multirow[t]{2}{*}{ Metschnikowia fructicola } & Apple & Penicillium expansum & Liu et al., 2011 \\
\hline & Grapefruit & Penicillium digitatum & Hershkovitz et al., 2013 \\
\hline Meyerozyma caribbica & Mango & Colletotrichum gloeosporioides & Bautista-Rosales et al., 2013 \\
\hline Pichia membranefaciens & Apple & $\begin{array}{l}\text { Monilinia fructicola, Penicillium } \\
\text { expansum, and Rhizopus } \\
\text { stolonifer }\end{array}$ & Chan and Tian, 2005 \\
\hline Rhodosporidium paludigenum & Cherry tomato & Botrytis cinerea & Wang et al., 2010 \\
\hline Rhodotorula mucilaginosa & Pear & Penicillium expansum & Hu et al., 2015 \\
\hline Rhodotorula rubra & Tomato & Botrytis cinerea & Dal Bello et al., 2008 \\
\hline \multirow[t]{3}{*}{ Wickerhamomyces (Pichia) anomalus } & Banana & $\begin{array}{l}\text { Colletotrichum musae, } \\
\text { Fusarium moniliforme and } \\
\text { Cephalosporium sp. }\end{array}$ & Lassois et al., 2008 \\
\hline & Orange & Penicillium digitatum & Aloui et al., 2015; Platania et al., 2012 \\
\hline & Papaya & Colletotrichum gloeosporioides & Lima et al., 2013 \\
\hline \multicolumn{4}{|l|}{ Commercial yeast-biocontrol products ${ }^{2}$} \\
\hline Aureobasidium pullulans & Pome & Penicillium, Botrytis, Monilinia & Boni Protect ${ }^{\S}$, Bio-Ferm, AT \\
\hline Candida oleophila & Pome & Penicillium, Botrytis & Nexy ${ }^{\S}$, Lesaffre, BE \\
\hline Metschnikowia fructicola & $\begin{array}{l}\text { Pome, table grape, stone fruits, } \\
\text { strawberry, sweet potato }\end{array}$ & $\begin{array}{l}\text { Penicillium, Botrytis, Rhizopus, } \\
\text { Aspergillus }\end{array}$ & Shemer ${ }^{\S}$, Bayer/Koppert, NL \\
\hline
\end{tabular}

${ }^{1}$ Preharvest application to prevent postharvest spoilage. ${ }^{2}$ Wisniewski et al. (2016).

receptor (R2), identified in the case of $\mathrm{K} 1$ toxin as Kre1p, an $\mathrm{O}$-glycosylated protein of the yeast cell surface (Breinig et al., 2002, 2004). After reaching the plasma membrane, $\mathrm{K} 1$ and $\mathrm{K} 2$ toxins disrupt its function by forming cationselective channels, and promoting the release of ATP and other metabolites, thus causing a lethal effect on the target cell (Liu et al., 2015). The K28 KT mode of action is very different, since it enters a sensitive target yeast cell by endocytosis, in a cell wall receptor-mediated manner (Schmitt and Breinig, 2006). The cell wall receptor for K28 toxin has been identified as a mannoprotein with high molecular mass (Liu et al., 2015). The K28 toxin is internalized through the secretory pathway (via Golgi and ER), and after entering the cytosol the $\beta$-subunit is ubiquitinated and degraded in the proteasome. The subsequently free small $\alpha$-subunit has been suggested to enter the nucleus without the help of an active nuclear import machinery, therefore by a so-called passive diffusion (Schmitt and Breinig, 2006). Once inside the nucleus, 
the K28 toxin kills the host cell by irreversibly blocking the DNA synthesis. The target cells arrest in early $S$ phase of the cell cycle, forming a medium-sized bud and a single, pre-replicated nucleus in the mother cell, eventually dying (Schmitt and Breinig, 2006).

The killer phenomenon, despite being best characterized in Saccharomyces cerevisiae, is not confined to this yeast species, rather it is often found in other yeast species and genera (Magliani et al., 1997; Schmitt and Breinig, 2002). Some of these were described to damage the plasma membrane, very similarly to the Saccharomyces cerevisiae K1 toxin. This is the case of the KTs produced by Pichia kluyveri (Ahmed et al., 1999), Pichia membranifaciens (Santos and Marquina, 2004; Santos et al., 2009), Pichia farinosa (Suzuki et al., 2001) and Zygosaccharomyces bailii (Weiler and Schmitt, 2003). Other killer mechanisms include the damage of the cell wall upon the inhibition of the synthesis of $\beta$-glucans. Examples of this mode of action are the toxins produced by Hansenula mrakii (previously Williopsis mrakii) (Marquina et al., 2002), Wickerhamomyces anomalus (formerly designated Pichia anomala or Hansenula anomala) (Wang et al., 2007), Williopsis saturnus (Guyard et al., 2002; Peng et al., 2010), and Kluyveromyces phaffii (Comitini et al., 2009). Yet other yeast KTs act by blocking the cell cycle, namely the one produced by Kluyveromyces lactis (Klassen et al., 2004), and by triggering DNA damaging and the induction of apoptosis, which is the case of the toxins secreted by Pichia acaciae (Klassen and Meinhardt, 2005) and Wingea robertsiae (Klassen and Meinhardt, 2002). The blocking of calcium uptake was also described as killer mode of action, namely in the case of Ustilago maydis (Gage et al., 2001). Although there are plenty of reports in the literature regarding the interaction of non-Saccharomyces killer yeasts with a vast variety of sensitive targets, the actual mechanisms involved remain mostly unknown or superficially studied at the molecular level.

Several other mechanisms of yeast antagonism have been proposed that do not involve the secretion of a peptide/protein that may be classified as a KT. Other proteins that are secreted by the yeast and antagonize filamentous fungi are lytic enzymes that destroy the fungal cell wall (Spadaro and Gullino, 2004). This kind of antagonism is considered a form of mycoparasitism. An example is the manner in which Pichia guilliermondii antagonizes Botrytis cinerea (Wisniewski et al., 1991). The authors observed that the fungus cell wall glucans and a yeast-secreted $\beta-(1-3)$ glucanase form a lectin-like interaction resulting in a strong attachment of the antagonist to the fungal pathogen which culminates with the lysis of fungal cells. Yeasts that antagonize other yeasts can also produce several volatile compounds against filamentous fungi, like low molecular weight lipophilic compounds that inhibit the target growth (Mari et al., 2016). This is the case of the yeast Aureobasidium pullulans that produces 2-methyl1-butanol, 3-methyl-1-butanol, 2-phenethyl alcohol and 2methyl-1-propanol, with inhibitory effect against Botrytis cinerea, Colletotrichum acutatum, Penicillium expansum, Penicillium digitatum, and Penicillium italicum (Di Francesco et al., 2015). Interestingly, it appears that antagonizing yeasts may operate in different ways also because in some cases they strongly attach to the fungus hyphae. This was described in detail for the case of the yeasts Pichia membranefaciens and Cryptococcus albidus when challenged with three phytopathogenic fungi causing the postharvest deterioration of nectarines and apples (Monilinia fructicola, Penicillium expansum, and Rhizopus stolonifer) (Chan and Tian, 2005).

Another effective mechanism of antagonism and possibly the most common is competition. Microbes compete for space, for oxygen and of course for nutrients, such as carbohydrates, vitamins, minerals, and amino acids (Spadaro and Droby, 2016). Yeasts grow much faster than filamentous fungi, being thus able to quickly colonize the niches that fungi can occupy, such as plant wounds or tissue lesions, forming colonies or biofilms (Andrews et al., 1994). Increasingly bigger yeast populations reduce the amount of nutrients available for fungi and make them difficult to access (Zhang D. et al., 2010). In the case of micronutrients, iron plays a crucial role in the growth, development and virulence of the fungal pathogens (Saravanakumar et al., 2008). To compete with the pathogens for iron, yeasts secrete siderophores that deplete iron from the growth medium such as pulcherrimin, produced by Metschnikowia pulcherrima to compete with Botrytis cinerea, Alternaria alternata, and Penicillium expansum (Saravanakumar et al., 2008).

Ultimately, the efficiency of the antagonism is affected by environmental constraints (Syed Ab Rahman et al., 2018), and each mechanism of action depends on a specific interaction between the pathogen and the antagonizing organism but also between either and the host. It has been described that antagonizing yeasts may help the host by alleviating the production of ROS induced by the pathogen (Liu et al., 2013). The production of ROS is actually not confined to plants themselves, but also happens in fruits during postharvest processes. This was observed to occur when yeasts such as Cryptococcus laurentii and Rhodotorula glutinis, which exhibit antagonistic activity against the postharvest pathogens Botrytis cinerea and Penicillium expansum, were applied to fruit surfaces and wounds (Castoria et al., 2003). Concurrently, a biofilm of a Saccharomyces cerevisiae strain isolated from wine prevented the spoilage of apples by Penicillium expansum (Scherm et al., 2003). The potential of killer yeasts has often been recognized, but their use seldom put to practice for economically viable processes. In biotechnology, yeast-toyeast antagonism has been mostly successfully applied in the control of wine and brewery processes, to avoid secondary fermentations producing undesirable compounds (Hatoum et al., 2012; Mehlomakulu et al., 2014; Oro et al., 2016). Another example of successfully commercialized application of a killer yeast is that of Debaryomyces hansenii, used in the prevention of spoilage of dairy products, such as milk and yogurt (Liu and Tsao, 2008), as well as in the extension of shelf-life of dry-cured meats and dry-fermented sausages (Andrade et al., 2014; Núñez et al., 2015). The spoilage prevention by yeasts extends to the postharvest protection of fruits from fungal spoilage, which acknowledges that yeasts can display significant antimycotic activity (Table 1). The majority of these antagonistic 
yeasts are naturally present on fruit and vegetable surfaces (Suzzi et al., 1995) but can be also obtained from other sources such as the phyllosphere (Kalogiannis et al., 2006), the rhizosphere (Long et al., 2005) or the soil (Zhao et al., 2012). The advantages of using naturally occurring yeasts strains are those of overcoming the negative effects of needed adaptation to the biophysical and biochemical specificities of the contaminated niches.

\section{ADVANTAGES AND CHALLENGES OF MICROBIAL WARFARE}

The use of live antagonist microorganisms or their nanoconjugated bio-derived toxins to manage phytopathogenic diseases would offer a great number of advantages over chemical fungicides or extensive pruning, including the safer field application methods and the reduced costs of production (Bonaterra et al., 2012), offering an environmentally friendly and bio-sustainable alternative to manage fungal diseases, provided the right microorganism is used. Any such option has to be primarily challenged with tests in planta and in field. Moreover, the solution, as mentioned above, has to be proven unharmful to human or animal cells (Ocampo-Suarez et al., 2017), as well as easily degradable so that its prevalence in the agriculture ecosystems does not generate a potential accumulation-derived harmful effect over time, and non-ecotoxic allowing the ecosystem functions to prevail (Liu et al., 2013). Finally, the commercial viability of any biocontrol agent needs to be subsequently assessed in pilot, semi-commercial and largescale commercial studies, prior to regulatory licensing from the respective regulatory agencies (Droby et al., 2009). The final approval needs to be based on the actual disease control efficacy and also the evaluation of the safety of the formulated product (Dukare et al., 2018). For this reason, and despite the recognition of the efficiency of microbial antagonisms and the theoretical advantages of their use, only a limited number of products based on biocontrol agents have been formulated and commercialized over the past decades (Dukare et al., 2018). These products are registered for using mainly against some postharvest fungal phytopathogenic diseases of fruits and vegetables (Sharma et al., 2009; Sundh and Melin, 2011; Dukare et al., 2018). As an example, Nexy ${ }^{\circledR}$ (Table 1) a formulation of water dispersed granules of living biomass of the yeast Candida oleophila, has been approved and commercialized in the EU against postharvest spoilage of stored fruits, namely against Penicillium expansum and Botrytis cinerea in apples, Penicillium spp. in citrus fruits and Colletotrichum musae in bananas (Ballet et al., 2016).

The microorganisms described to antagonize filamentous fungi include endophytic fungi, which have been suggested as biocontrol agents of several cacao plant diseases (Arnold et al., 2003). These authors demonstrated that inoculating cacao plant leaf tissues with fungal endophytes isolated from naturally infected asymptomatic hosts, significantly decreased the damage provoked by the foliar pathogen Phytophthora sp. Fungal endophytes isolated from healthy cacao plant tissues also displayed in vitro antagonism response against major pathogens of cacao, including the WBD (Mejía et al., 2008). The antagonism mode of action was reported as competition for nutrients or antibiosis (Mejía et al., 2008). WBD fungus was though not killed by any of the tested endophytic fungal strains. In another study (Rubini et al., 2005), the endophytic fungus Gliocladium catenulatum, isolated from healthy cacao plants, was able to reduce the incidence of WBD in cacao seedlings to $70 \%$ in greenhouse conditions. Again, Moniliophthora perniciosa was not killed by Gliocladium catenulatum. Instead, another endophytic isolate from Trichoderma stromaticum parasites internally Moniliophthora perniciosa, preventing its reproduction (Samuels et al., 2000; Pomella et al., 2007; Medeiros et al., 2010). No information is presently available as to the molecular basis of this antagonism or the death process associated.

The Brazilian governmental organization CEPLAC (Executive Committee of the Cocoa Farming Plan) has produced and developed a semi-commercial product named Tricovab ${ }^{\circledR}$, that is available to Brazilian farmers on a by request basis. This biocontrol agent is multiplied in silos of rice grains, in which surface the fungus multiplies. The local farmers receive the packed dry rice grains and activate the product by making a suspension in water that can be spread directly in the plantation ${ }^{3}$. Despite being an alternative with relatively high efficacy compared to the other methods, it is a very expensive methodology. The high price derives from the very complex and expensive Trichoderma stromaticum rice-dependent production system, reason why this method is entirely subsidized by the federal government and supplied as a service from the Brazilian Ministry of Agriculture and developed at its R\&D unit CEPLAC ${ }^{4}$ (Silveira, 2013). Additionally, the waste of large amounts of rice diverted from food resource, and the unavailability of the product to local farmers located far from the CEPLAC distribution centers contribute to the impracticability of this solution, reinforcing the urgent need for strategies to control the WBD that are more sustainable. The utilization of antagonistic yeasts as biocontrol agents could be one such case. The possibility of using yeasts for this purpose is very attractive because, unlike filamentous fungi or bacteria, (i) they are ubiquitously found in the phytobiome, displaying a degree of biodiversity that allows the finding of natural and specific antagonisms, (ii) they are GRAS (Generally Recognized as Safe) for humans and animals and therefore safe to manipulate, (iii) they generally promote the wellbeing of the plants, (iv) they are environmental-friendly microorganisms, and (v) they can be cheaply multiplied to very high amounts, particularly in Brazil, in view of the long tradition of yeast-fermentation industries (Figure 1). Two yeast strains were previously shown to strongly antagonize Moniliophthora perniciosa in vitro, a Candida sp. strain isolated from an organic farm soil and a Dipodascus capitatus strain isolated from the jackfruit (Cabral et al., 2009). These or other yeast strains were

\footnotetext{
${ }^{3}$ www.ceplac.gov.br

${ }^{4}$ Available at: https://www.servicos.gov.br/servico/comprar-biofungicidatricovab-para-a-vassoura-de-bruxa-do-cacaueiro (accessed February 18, 2019).
} 
not further explored in in field assays, neither was their mode of action studied.

\section{CONCLUDING REMARKS}

The cacao producers from Central and South America, where the WBD is a threat, are being encouraged to substitute their plantations with more resistant cacao plant varieties ${ }^{5}$. This is an expensive and drastic solution for plantations still operating, implicating a production lag phase that not all producers can afford. Moreover, more resistant varieties cannot avoid the incoming of more virulent fungal strains, which appears to be a world-wide trend (Fisher et al., 2012). The use of natural microbial biocides, has in favor not only the health, environment and economic arguments above stated, but also the almost infinite microbial biodiversity available to continuously feed the search for a suitable killer for each emerging or evolving phytopathology. This review calls the attention to this possibility, in particular using phytobiome-originating yeasts, as a sustainable alternative strategy to manage the Witches' Broom Disease of cacao, contributing to ease the associated severe social and economic implications to the life of millions of people.

${ }^{5}$ Available at: https://www.icco.org/about-cocoa/pest-a-diseases.html (accessed February 18, 2019).

\section{REFERENCES}

Ahmed, A., Sesti, F., Ilan, N., Shih, T. M., Sturley, S. L., and Goldstein, S. A. (1999). A molecular target for viral killer toxin: TOK1 potassium channels. Cell 99, 283-291. doi: 10.1016/S0092-8674(00)81659-1

Aime, M. C., and Phillips-Mora, W. (2005). The causal agents of witches' broom and frosty pod rot of cacao (chocolate, Theobroma cacao) form a new lineage of Marasmiaceae. Mycologia 97, 1012-1022. doi: 10.1080/15572536. 2006.11832751

Alghuthaymi, M. A., Almoammar, H., Rai, M., Said-Galiev, E., and AbdElsalam, K. A. (2015). Myconanoparticles: synthesis and their role in phytopathogens management. Biotechnol. Biotechnol. Equip. 29, 221-236. doi: 10.1080/13102818.2015.1008194

Almeida, O. C., Chiacchio, F., and Rocha, H. M. (1997). Survival of Crinipellis perniciosa (Stahel) Singer on dried brooms of cacao (Theobroma cacao L.) in the State of Bahia (in Portuguese). Agrotrópica 9, 23-28.

Aloui, H., Licciardello, F., Khwaldia, K., Hamdi, M., and Restuccia, C. (2015). Physical properties and antifungal activity of bioactive films containing Wickerhamomyces anomalus killer yeast and their application for preservation of oranges and control of postharvest greenmold caused by Penicillium digitatum. Int. J. Food Microbiol. 200, 22-30. doi: 10.1016/j.ijfoodmicro.2015. 01.015

Andrade, M. J., Thorsen, L., Rodríguez, A., Córdoba, J. J., and Jespersen, L. (2014). Inhibition of ochratoxigenic moulds by Debaryomyces hansenii strains for biopreservation of dry-cured meat products. Int. J. Food Microbiol. 170, 70-77. doi: 10.1016/j.ijfoodmicro.2013.11.004

Andrews, J. H., Harris, R. F., Spear, R. N., Lau, G. W., and Nordheim, E. V. (1994). Morphogenesis and adhesion of Aureobasidium pullulans. Can. J. Microbiol. 40, 6-17. doi: 10.1139/m94-002

Arnold, A. E., Mejía, L. C., Kyllo, D., Rojas, E. I., Maynard, Z., Robbins, N., et al. (2003). Fungal endophytes limit pathogen damage in a tropical tree. Proc. Natl. Acad. Sci. U.S.A. 100, 15649-15654. doi: 10.1073/pnas.2533483100

Bailey, B. A., Bae, H., Strem, D., Roberts, D. P., Thomas, S. E., Crozier, J., et al. (2006). Fungal and plant gene expression during the colonization of cacao seedlings by endophytic isolates of four Trichoderma species. Planta 224, 1449-1464. doi: 10.1007/s00425-006-0314-0
This is a research area with plenty to explore and a predictable great importance in the field of plant pathology in the next years.

\section{AUTHOR CONTRIBUTIONS}

PF wrote the manuscript together with FC and CL. All authors read and approved the final manuscript.

\section{FUNDING}

This work was supported by the strategic programme UID/BIA/04050/2013 (POCI-01-0145-FEDER-007569) funded by national funds through the FCT I.P. and by the ERDF through the COMPETE2020 - Programa Operacional Competitividade e Internacionalização (POCI), and the project EcoAgriFood (NORTE-01-0145-FEDER-000009), supported by the Norte Portugal Regional Operational Programme (NORTE 2020) under the PORTUGAL 2020 Partnership Agreement through the European Regional Development Fund (ERDF). PF is a Ph.D. student of the Doctoral Programme in Applied and Environmental Microbiology (DP_AEM) and FCT grantee $\mathrm{PD} / \mathrm{BD} / 113810 / 2015$.

Baker, S., Kumar, M., Santosh, P., Rakshith, D., and Satish, S. (2015). Extracellular synthesis of silver nanoparticles by novel Pseudomonas veronii AS41G inhabiting Annona squamosa L. and their bactericidal activity. Spectrochim. Acta A Mol. Biomol. Spectrosc. 136, 1434-1440. doi: 10.1016/j.saa.2014.10.033

Baker, S., Volova, T., Prudnikova, S. V., Satish, S., and Prasad, M. N. N. (2017). Nanoagroparticles emerging trends and future prospect in modern agriculture system. Environ. Toxicol. Pharmacol. 53, 10-17. doi: 10.1016/j.etap.2017.04.012

Ballet, N., Souche, J. L., and Vandekerckove, P. (2016). Efficacy of Candida oleophila, strain $\mathrm{O}$, in preventing postharvest diseases of fruits. Acta Hortic. 1144, 105-112. doi: 10.17660/ActaHortic.2016.1144.15

Bautista-Rosales, P. U., Calderon-Santoyo, M., Servín-Villegas, R., Ochoa-Álvarez, N. A., and Ragazzo-Sánchez, J. A. (2013). Action mechanisms of the yeast Meyerozyma caribbica for the control of the phytopathogen Colletotrichum gloeosporioides in mangoes. Biol. Control 65, 293-301. doi: 10.1016/j.biocontrol. 2013.03.010

Bevan, E. A., and Makower, M. (1963). "The physiological basis of the killercharacter in yeast," in Proceedings of the Genetics Today, XIth International Congress of Genetics, Vol. 1, ed. S. J. Geerts (Oxford: Pergamon Press), 202-203.

Bonaterra, A., Badosa, E., Cabrefiga, J., Francés, J., and Montesinos, E. (2012). Prospects and limitations of microbial pesticides for control of bacterial and fungal pomefruit tree diseases. Trees 26, 215-226. doi: 10.1007/s00468-0110626-y

Bowers, J. H., Bailey, B. A., Hebbar, P. K., Sanogo, S., and Lumsden, R. D. (2001). The impact of plant diseases on world chocolate production. Plant Health Prog. doi: 10.1094/PHP-2001-0709-01-RV

Breinig, F., Schleinkofer, K., and Schmitt, M. J. (2004). Yeast Kre1p is GPIanchored and involved in both cell wall assembly and architecture. Microbiology 150, 3209-3218. doi: 10.1099/mic.0.27175-0

Breinig, F., Tipper, D. J., and Schmitt, M. J. (2002). Krelp, the plasma membrane receptor for the yeast K1 viral toxin. Cell 108, 395-405. doi: 10.1016/S00928674(02)00634-7

Cabral, A. S., de Carvalho, P. M. B., Pinotti, T., Hagler, A. N., MendonçaHagler, L. C. S., and Macrae, A. (2009). Killer yeasts inhibit the growth of the phytopathogen Moniliophthora perniciosa, the causal agent of Witches' Broom disease. Braz. J. Microbiol. 40, 108-110. doi: 10.1590/S151783822009000100018 
Cárdenas-Monroy, C. A., Pohlmann, T., Piñón-Zárate, G., Matus-Ortega, G., Guerra, G., Feldbrügge, M., et al. (2017). The mitochondrial alternative oxidase Aoxl is needed to cope with respiratory stress but dispensable for pathogenic development in Ustilago maydis. PLoS One 12:e0173389. doi: 10.1371/journal. pone. 0173389

Carvalho, F. P. (2006). Agriculture, pesticides, food security and food safety. Environ. Sci. Policy 9, 685-692. doi: 10.1016/j.envsci.2006.08.002

Castoria, R., Caputo, L., De Curtis, F., and De Cicco, V. (2003). Resistance of postharvest biocontrol yeasts to oxidative stress: a possible new mechanism of action. Phytopathology 93, 564-572. doi: 10.1094/PHYTO.2003.93.5.564

Celis, Z. C., Moreno, D. G., Sequeda-castañeda, L. G., García, A., Albarracín, D. M., Charry, B., et al. (2014). Determining the effectiveness of Candida guilliermondii in the biological control of Rhizopus stolonifer in postharvest tomatoes. Univ. Sci. 19, 51-62.

Cervantes, C., and Gutierrez-Corona, F. (1994). Copper resistance mechanisms in bacteria and fungi. FEMS Microbiol. Rev. 14, 121-137. doi: 10.1111/j.1574-6976. 1994.tb00083.x

Chan, Z., and Tian, S. P. (2005). Interaction of antagonistic yeasts against postharvest pathogens of apple fruit and possible mode of action. Postharvest Biol. Technol. 36, 215-223. doi: 10.1016/j.postharvbio.2005.01.001

Chanchaichaovivat, A., Ruenwongsa, P., and Panijpan, B. (2007). Screening and identification of yeast strains from fruits and vegetables: potential for biological control of postharvest chilli anthracnose (Colletotrichum capsici). Biol. Control 42, 326-335. doi: 10.1016/j.biocontrol.2007.05.016

Chaudhuri, M., Ott, R. D., and Hill, G. C. (2006). Trypanosome alternative oxidase: from molecule to function. Trends Parasitol. 22, 484-491. doi: 10.1016/j.pt. 2006.08.007

Choudhary, D. K., and Johri, B. N. (2009). "Basidiomycetous Yeasts: Current Status," in Yeast Biotechnology: Diversity and Applications, eds T. Satyanarayana and G. Kunze (Berlin: Springer), 19-46. doi: 10.1007/978-1-4020-8292-4_2

Comitini, F., Mannazzu, I., and Ciani, M. (2009). Tetrapisispora phaffii killer toxin is a highly specific $\beta$-glucanase that disrupts the integrity of the yeast cell wall. Microb. Cell Fact. 8, 55. doi: 10.1186/1475-2859-8-55

Culotta, V. C., Joh, H. D., Lin, S. J., Slekar, K. H., and Strain, J. (1995). A Physiological role for Saccharomyces cerevisiae Copper/Zinc Superoxide Dismutase in Copper Buffering. J. Biol. Chem. 270, 29991-29997. doi: 10.1074/ jbc. 270.50 .29991

Dal Bello, G., Mónaco, C., Rollan, M. C., Lampugnani, G., Arteta, N., Abramoff, C., et al. (2008). Biocontrol of postharvest grey mould on tomato by yeasts. J. Phytopathol. 156, 257-263. doi: 10.1111/j.1439-0434.2007.01351.x

de Oliveira, B. V., Teixeira, G. S., Reis, O., Barau, J. G., Teixeira, P. J., do Rio, M. C., et al. (2012). A potential role for an extracellular methanol oxidase secreted by Moniliophthora perniciosa in Witches' broom disease in cacao. Fungal Genet. Biol. 49, 922-932. doi: 10.1016/j.fgb.2012.09.001

Del Rio, D., Stewart, A. J., and Pellegrini, N. (2005). A review of recent studies on malondialdehyde as toxic molecule and biological marker of oxidative stress. Nutr. Metab. Cardiovasc. Dis. 15, 316-328. doi: 10.1016/j.numecd.2005.05.003

Di Francesco, A., Ugolini, L., Lazzeri, L., and Mari, M. (2015). Production of volatile organic compounds by Aureobasidium pullulans as a potential mechanism of action against postharvest fruit pathogens. Biol. Control 81, 8-14. doi: 10.1016/j.biocontrol.2014.10.004

Doty, S. L. (2013). "Endophytic Yeasts: Biology and Applications," in Symbiotic Endophytes, Soil Biology, ed. R. Aroca (Berlin: Springer), 335-343. doi: 10.1007/ 978-3-642-39317-4_17

Droby, S. (2006). Improving quality and safety of fresh fruit and vegetables after harvest by the use of biocontrol agents and natural materials. Acta Hortic. 709, 45-51. doi: 10.17660/ActaHortic.2006.709.5

Droby, S., Wisniewski, M., Macarisin, D., and Wilson, C. (2009). Twenty years of postharvest biocontrol research: is it time for a new paradigm? Postharvest Biol. Technol. 52, 137-145. doi: 10.1016/j.postharvbio.2008.11.009

Dukare, A. S., Paul, S., Nambi, V. E., Gupta, R. K., Singh, R., Sharma, K., et al. (2018). Exploitation of microbial antagonists for the control of postharvest diseases of fruits: a review. Crit. Rev. Food Sci. Nutr. 16, 1-16. doi: 10.1080/ 10408398.2017.1417235

Elthon, T. E., and McIntosh, L. (1987). Identification of the alternative terminal oxidase of higher plant mitochondria. Proc. Natl. Acad. Sci. U.S.A. 84, 83998403. doi: 10.1073/pnas.84.23.8399
Evans, H. C. (1980). Pleomorphism in Crinipellis perniciosa, causal agent of witches' broom disease of cocoa. Trans. Br. Mycol. Soc. 74, 515-523. doi: 10. 1016/S0007-1536(80)80051-9

Fisher, M. C., Hawkins, N. J., Sanglard, D., and Gurr, S. J. (2018). Worldwide emergence of resistance to antifungal drugs challenges human health and food security. Science 360, 739-742. doi: 10.1126/science.aap7999

Fisher, M. C., Henk, D. A., Briggs, C. J., Brownstein, J. S., Madoff, L. C., McCraw, S. L., et al. (2012). Emerging fungal threats to animal, plant and ecosystem health. Nature 484, 186-194. doi: 10.1038/nature10947

Gadd, G. M., Chudek, J. A., Foster, R., and Reed, R. H. (1984). The Osmotic Responses of Penicillium ochro-chloron: changes in internal solute levels in response to copper and salt stres. J. Gen. Microbiol. 130, 1969-1975. doi: 10. 1099/00221287-130-8-1969

Gage, M. J., Bruenn, J., Fischer, M., Sanders, D., and Smith, T. J. (2001). KP4 fungal toxin inhibits growth in Ustilago maydis by blocking calcium uptake. Mol. Microbiol. 41, 775-785. doi: 10.1046/j.1365-2958.2001.02554.x

Griffith, G. W., Nicholson, J., Nenninger, A., Birch, R. N., and Hedger, J. N. (2003). Witches' brooms and frosty pods: two major pathogens of cacao. N. Z. J. Botany 41, 423-435. doi: 10.1080/0028825X.2003.9512860

Guyard, C., Dehecq, E., Tissier, J. P., Polonelli, L., Dei-Cas, E., Cailliez, J. C., et al. (2002). Involvement of $\beta$-glucans in the wide-spectrum antimicrobial activity of Williopsis saturnus var. mrakii MUCL 41968 killer toxin. Mol. Med. 8, 686-694. doi: 10.1007/BF03402032

Hatoum, R., Labrie, S., and Fliss, I. (2012). Antimicrobial and probiotic properties of yeasts: from fundamental to novel applications. Front. Microbiol. 3:421. doi: 10.3389/fmicb.2012.00421

Hershkovitz, V., Sela, N., Taha-Salaime, L., Liu, J., Rafael, G., Kessler, C., et al. (2013). De-novo assembly and characterization of the transcriptome of Metschnikowia fructicola reveals differences in gene expression following interaction with Penicillium digitatum and grapefruit peel. BMC Genomics 14:168. doi: 10.1186/1471-2164-14-168

Hu, H., Yan, F., Wilson, C., Shen, Q., and Zheng, X. (2015). The ability of a coldadapted Rhodotorula mucilaginosa strain from Tibet to control blue mold in pear fruit. Antonie van Leeuwenhoek 108, 1391-1404. doi: 10.1007/s10482-0150593-1

Husak, V. (2015). Copper and copper-containing pesticides: metabolism, toxicity and oxidative stress. J. Vasyl Stefanyk Precarpathian Natl. Univ. 2, 38-50. doi: 10.15330/jpnu.2.1.38-50

Joseph-Horne, T., Hollomon, D. W., and Wood, P. M. (2001). Fungal respiration: a fusion of standard and alternative components. Biochim. Biophys. Acta 1504, 179-195. doi: 10.1016/S0005-2728(00)00251-6

Joubert, P. M., and Doty, S. L. (2018). "Endophytic Yeasts: Biology, Ecology and Applications," in Endophytes of Forest Trees. Forestry Sciences, eds A. Pirttilä and A. Frank (Cham: Springer), 3-14. doi: 10.1007/978-3-319-89833-9_1

Kalogiannis, S., Tjamos, S. E., Stergiou, A., Antoniou, P. P., Ziogas, B. N., and Tjamos, E. C. (2006). Selection and evaluation of phyllosphere yeasts as biocontrol agents against grey mould of tomato. Eur. J. Plant Pathol. 116, 69-76. doi: 10.1007/s10658-006-9040-5

Klassen, R., and Meinhardt, F. (2002). Linear plasmids pWR1A and pWR1B of the yeast Wingea robertsiae are associated with a killer phenotype. Plasmid 48, 142-148. doi: 10.1016/S0147-619X(02)00101-4

Klassen, R., and Meinhardt, F. (2005). Induction of DNA damage and apoptosis in Saccharomyces cerevisiae by a yeast killer toxin. Cell. Microbiol. 7, 393-401. doi: 10.1111/j.1462-5822.2004.00469.x

Klassen, R., Teichert, S., and Meinhardt, F. (2004). Novel yeast killer toxins provoke S-phase arrest and DNA damage checkpoint activation. Mol. Microbiol. 53, 263-273. doi: 10.1111/j.1365-2958.2004.04119.x

Lassois, L., de Bellaire, L., and Jijakli, M. H. (2008). Biological control of crown rot of bananas with Pichia anomala strain K and Candida oleophila strain O. Biol. Control 45, 410-418. doi: 10.1016/j.biocontrol.2008.01.013

Lawrence, J. S., Campêlo, A., and Figueiredo, J. M. (1991). Diseases of cacao. li Fungal diseases which occur on the leaves, branches and trunk (in Portuguese). Agrotrópica 3, 1-14.

Lima, J. R., Gondim, D. M. F., Oliveira, J. T. A., Oliveira, F. S. A., Gonçalves, L. R. B., and Viana, F. M. P. (2013). Use of killer yeast in the management of postharvest papaya anthracnose. Postharvest Biol. Technol. 83, 58-64. doi: 10.1016/j.postharvbio.2013.03.014 
Liu, G. L., Chi, Z., Wang, G. Y., Wang, Z. P., Li, Y., and Chi, Z. M. (2015). Yeast killer toxins, molecular mechanisms of their action and their applications. Crit. Rev. Biotechnol. 35, 222-234. doi: 10.3109/07388551.2013.833582

Liu, J., Sui, Y., Wisniewski, M., Droby, S., and Liu, Y. (2013). Review: utilization of antagonistic yeasts tomanage postharvest fungal diseases of fruit. Int. J. Food Microbiol. 167, 153-160. doi: 10.1016/j.ijfoodmicro.2013.09.004

Liu, J., Wisniewski, M., Droby, S., Norelli, J., Hershkovitz, V., Tian, S., et al. (2012). Increase in antioxidant gene transcripts, stress tolerance and biocontrol efficacy of Candida oleophila following sublethal oxidative stress exposure. FEMS Microbiol. Ecol. 80, 578-590. doi: 10.1111/j.1574-6941.2012.01324.x

Liu, J., Wisniewski, M., Droby, S., Tian, S., Hershkovitz, V., and Tworkoski, T. (2011). Effect of heat shock treatment on stress tolerance and biocontrol efficacy of Metschnikowia fructicola. FEMS Microbiol. Ecol. 76, 145-155. doi: 10.1111/j. 1574-6941.2010.01037.x

Liu, S. Q., and Tsao, M. (2008). Biocontrol of dairy moulds by antagonistic dairy yeast Debaryomyces hansenii in yoghurt and cheese at elevated temperatures. Food Control 20, 852-855. doi: 10.1016/j.foodcont.2008.10.006

Long, C. A., Wu, Z., and Deng, B. X. (2005). Biological control of Penicillium italicum of Citrus and Botrytis cinerea of Grape by Strain 34-9 of Kloeckera apiculata. Eur. Food Res. Technol. 221, 197-201. doi: 10.1007/s00217-0051199-z

Lukša, J., Podoliankaité, M., Vepštaitë, I., Strazdaitë-Žielienë, Ž, Urbonavièius, J., and Servienë, E. (2015). Yeast $\beta$-1,6-Glucan is a primary target for the Saccharomyces cerevisiae K2 Toxin. Eukaryotic Cell 14, 406-414. doi: 10.1128/ EC.00287-14

Luna, E. P. I. (2017). "Endophytic Yeast and Hosts: A Mutualistic Association Friendly to the Environment," in Old Yeasts - New Questions, eds C. Lucas and C. Pais (London: IntechOpen), 169-188.

Magliani, W., Conti, S., Gerloni, M., Bertolotti, D., and Polonelli, L. (1997). Yeast killer systems. Clin. Microbiol. Rev. 10, 369-400. doi: 10.1128/CMR.10.3.369

Mandal, G., Singh, D., and Sharma, R. R. (2007). Effect of hot water treatment and biocontrol agent (Debaryomyces hansenii) on shelf life of peach. Indian J. Hortic. $64,25-28$

Marelli, J.-P., Maximova, S. N., Gramacho, K. P., Kang, S., and Guiltinan, M. J. (2009). Infection Biology of Moniliophthora perniciosa on Theobroma cacao and alternate solanaceous hosts. Trop. Plant Biol. 2, 149-160. doi: 10.1007/s12042009-9038-1

Mari, M., Bautista-Baños, S., and Sivakumar, D. (2016). Decay control in the postharvest system: role of microbial and plant volatile organic compounds. Postharvest Biol. Technol. 122, 70-81. doi: 10.1016/j.postharvbio.2016. 04.014

Mari, M., Martini, C., Spadoni, A., Rouissi, W., and Bertolini, P. (2012). Biocontrol of apple postharvest decay by Aureobasidium pullulans. Postharvest Biol. Technol. 73, 56-62. doi: 10.1016/j.postharvbio.2012.05.014

Marquina, D., Santos, A., and Peinado, J. M. (2002). Biology of killer yeasts. Int. Microbiol. 5, 65-71. doi: 10.1007/s10123-002-0066-z

Maxwell, D. P., Wang, Y., and McIntosh, L. (1999). The alternative oxidase lowers mitochondrial reactive oxygen production in plant cells. Proc. Natl. Acad. Sci. U.S.A. 96, 8271-8276. doi: 10.1073/pnas.96.14.8271

McDonald, A. E., Vanlerberghe, G. C., and Taples, J. F. (2009). Alternative oxidase in animals: unique characteristics and taxonomic distribution. J. Exp. Biol. 212, 2627-2634. doi: 10.1242/jeb.032151

Medeiros, F. H. V., Pomella, A. W. V., de Souza, J. T., Niella, G. R., Valle, R., Bateman, R. P., et al. (2010). A novel, integrated method for management of witches' broom disease in Cacao in Bahia, Brazil. Crop Protect. 29, 704-711. doi: 10.1016/j.cropro.2010.02.006

Mehlomakulu, N. N., Setati, M. E., and Divol, B. (2014). Characterization of novel killer toxins secreted by wine-related non-Saccharomyces yeasts and their action on Brettanomyces spp. Int. J. Food Microbiol. 188, 83-91. doi: 10.1016/j. ijfoodmicro.2014.07.015

Meinhardt, L. W., Rincones, J., Bailey, B. A., Aime, M. C., Griffith, G. W., Zhang, D., et al. (2008). Moniliophthora perniciosa, the causal agent of witches' broom disease of cacao: what's new from this old foe? Mol. Plant Pathol. 9, 577-588. doi: 10.1111/j.1364-3703.2008.00496.x

Mejía, L. C., Rojas, E. I., Maynard, Z., Van Bael, S., Arnold, A. E., Hebbar, P., et al. (2008). Endophytic fungi as biocontrol agents of Theobroma cacao pathogens. Biol. Control 46, 4-14. doi: 10.1016/j.biocontrol.2008. 01.012
Mirković, B., Tanoviæ, B., Hrustiæ, J., Mihajloviæ, M., Steviæ, M., Delibašiæ, G., et al. (2015). Toxicity of copper hydroxide, dithianon, fluazinam, tebuconazole and pyraclostrobin to Didymella applanata isolates from Serbia. J. Environ. Sci. HealthPart B 50, 175-183. doi: 10.1080/03601234.2015.982414

Mondego, J. M., Carazzolle, M. F., Costa, G. G., Formighieri, E. F., Parizzi, L. P., Rincones, J., et al. (2008). A genome survey of Moniliophthora perniciosa gives new insights into Witches' broom disease of cacao. BMC Genomics 18:548. doi: 10.1186/1471-2164-9-548

Morales, H., Sanchis, V., Usall, J., Ramos, A. J., and Marín, S. (2008). Effect of biocontrol agents Candida sake and Pantoea agglomerans on Penicillium expansum growth and patulin accumulation in apples. Int. J. Food Microbiol. 122, 61-67. doi: 10.1016/j.ijfoodmicro.2007.11.056

Naiki, N. (1980). Role of superoxide dismutase in a copper-resistant strain of yeast. Plant Cell Physiol. 21, 775-783. doi: 10.1093/oxfordjournals.pcp.a076052

Nunes, C. A. (2012). Biological control of postharvest diseases of fruit. Eur. J. Plant Pathol. 133, 181-196. doi: 10.1007/s10658-011-9919-7

Núñez, F., Lara, M. S., Peromingo, B., Delgado, J., Sánchez-Montero, L., Andrade, M. J., et al. (2015). Selection and evaluation of Debaryomyces hansenii isolates as potential bioprotective agents against toxigenic penicillia in dry-fermented sausages. Food Microbiol. 46, 114-140. doi: 10.1016/j.fm.2014.07.019

O'Brien, P. A. (2017). Biological control of plant diseases. Aust. Plant Pathol. 46, 293-304. doi: 10.1007/s13313-017-0481-4

Ocampo-Suarez, I. B., López, Z., Calderón-Santoyo, M., Ragazzo-Sánchez, J. A., and Knauth, P. (2017). Are biological control agents, isolated from tropical fruits, harmless to potential consumers? Food Chem. Toxicol. 109, 1055-1062. doi: 10.1016/j.fct.2017.05.010

Oliveira, M. L., and Luz, E. D. M. N. (2005). Identificação e manejo das principais doenças do cacaueiro no Brasil. Ilhéus: CEPLAC.

Oro, L., Ciani, M., Bizzaro, D., and Comitini, F. (2016). Evaluation of damage induced by Kwkt and Pikt zymocins against Brettanomyces/Dekkera spoilage yeast, as compared to sulphur dioxide. J. Appl. Microbiol. 121, 207-214. doi: 10.1111/jam.13121

Pal, K. K., and McSpadden Gardener, B. (2006). Biological control of plant pathogens. Plant Health Instruc. doi: 10.1094/PHI- A-2006-1117-02

Parisi, C., Vigani, M., and Rodríguez-Cerezo, E. (2015). Agricultural nanotechnologies: what are the current possibilities? Nano Today 10, 124-127. doi: 10.1016/j.nantod.2014.09.009

Parizi, M. A., Moradpour, Y., Roostaei, A., Khani, M., Negahdari, M., and Rahimi, G. (2014). Evaluation of the antifungal effect of magnesium oxide nanoparticles on Fusarium oxysporum F. Sp. lycopersici, pathogenic agent of tomato. Eur. J. Exp. Biol. 4, 151-156.

Peng, Y., Chi, Z., Wang, X., and Li, J. (2010). $\beta$-1,3-Glucanase inhibits activity of the killer toxin produced by the marine-derived yeast Williopsis saturnus WC91-2. Mar. Biotechnol. 12, 479-485. doi: 10.1007/s10126-009-9243-9

Pereira, J. L. (1999). "Renewed advance of witches' broom disease of cocoa: 100 years later," in Proceedings of the International Cocoa Research Conference, 12th, Salvador, Bahía, Brasil, 1996, (Lagos: Cocoa Producers' Alliance), 87-91.

Pereira, J. L., Ram, A., Figueiredo, J. M., and Almeida, L. C. C. (1989). The first ocurrence of witches' broom in the principal cocoa growing region of Brazil (in Portuguese). Agrotrópica 1, 79-81.

Pires, A. B. L., Gramacho, K. P., Silva, D. C., Góes-Neto, A., Silva, M. M., MunizSobrinho, J. S., et al. (2009). Early development of Moniliophthora perniciosa basidiomata and developmentally regulated genes. BMC Microbiol. 9:158. doi: 10.1186/1471-2180-9-158

Platania, C., Restuccia, C., Muccilli, S., and Cirvilleri, G. (2012). Efficacy of killer yeasts in the biological control of Penicillium digitatum on Tarocco orange fruits (Citrus sinensis). Food Microbiol. 30, 219-225. doi: 10.1016/j.fm.2011.12.010

Pohlan, H. A. J., and Pérez, V. D. (2010). "Growth and Production of Cacao," in Soils, Plant Growth and Crop Production Encyclopedia of Life Support Systems (EOLSS), Vol. III, ed. W. H. Verheye (Oxford: EOLSS Publishers).

Pomella, A. W. V., De Souza, J. T., Niella, G. R., Bateman, R. P., Hebbar, P. K., Loguercio, L. L., et al. (2007). "Trichoderma stromaticum for management of witches' broom in Brazil," in Biological Control: A Global Perspective, Case Studies from Around the World, eds C. Vincent, M. Goettel, and G. Lazarovits (Wallingford: CABI Publishing), 210-217. doi: 10.1079/9781845932657.0210

Price, C. L., Parker, J. E., Warrilow, A. G., Kelly, D. E., and Kelly, S. L. (2015). Azole fungicides - understanding resistance mechanisms in agricultural fungal pathogens. Pest Manag. Sci. 71, 1054-1058. doi: 10.1002/ps.4029 
Purdy, L. H., and Schmidt, R. A. (1996). STATUS OF CACAO WITCHES' BROOM: biology, epidemiology, and management. Annu. Rev. Phytopathol. 34, 573-594. doi: 10.1146/annurev.phyto.34.1.573

Rincones, J., Scarpari, L. M., Carazzolle, M. F., Mondego, J. M., Formighieri, E. F., Barau, J. G., et al. (2008). Differential gene expression between the biotrophiclike and saprotrophic mycelia of the witches' broom pathogen Moniliophthora perniciosa. Mol. Plant Microbe Interact. 21, 891-908. doi: 10.1094/MPMI-21-70891

Robert, V., Cardinali, G., and Casadevall, A. (2015). Distribution and impact of yeast thermal tolerance permissive for mammalian infection. BMC Biol. 13:18. doi: 10.1186/s12915-015-0127-3

Robiglio, A., Sosa, M. C., Lutz, M. C., Lopes, C. A., and Sangorrín, M. P. (2011). Yeast biocontrol of fungal spoilage of pears stored at low temperature. Int. J. Food Microbiol. 147, 211-216. doi: 10.1016/j.ijfoodmicro.2011.04.007

Rocha, H. M., and Wheeler, B. E. J. (1985). Factors influencing the production of basidiocarps and the deposition and germination of basidiospores of Crinipellis perniciosa, the causal agent of witches' broom disease on cocoa (Theobroma cacao L.). Plant Pathol. 34, 319-328. doi: 10.1111/j.1365-3059.1985.tb01368.x

Rodríguez-Cousiño, N., Maqueda, M., Ambrona, J., Zamora, E., Esteban, R., and Ramírez, M. (2011). A New wine Saccharomyces cerevisiae killer toxin (klus), encoded by a double-stranded RNA virus, with broad antifungal activity is evolutionarily related to a chromosomal host gene. Appl. Environ. Microbiol. 77, 1822-1832. doi: 10.1128/AEM.02501-10

Rogov, A. G., and Zvyagilskaya, R. A. (2015). Physiological role of alternative oxidase (from yeasts to plants). Biochemistry 80, 400-407. doi: 10.1134/ S0006297915040021

Rosa-Magri, M. M., Tauk-Tornisielo, S. M., and Ceccato-Antonini, S. R. (2011). Bioprospection of yeasts as biocontrol agents against phytopathogenic molds. Brazil. Arch. Biol. Technol. 54, 1-5. doi: 10.1590/S1516-89132011000100001

Rubini, M. R., Silva-Ribeiro, R. T., Pomella, A. W., Maki, C. S., Araújo, W. L., dos Santos, D. R., et al. (2005). Diversity of endophytic fungal community of cacao (Theobroma cacao L.) and biological control of Crinipellis perniciosa, causal agent of Witches' broom disease. Int. J. Biol. Sci. 1, 24-33. doi: 10.7150/ijbs.1.24

Ruy, F., Vercesi, A. E., and Kowaltowski, A. J. (2006). Inhibition of specific electron transport pathways leads to oxidative stress and decreased Candida albicans proliferation. J. Bioenerg. Biomembr. 38, 129-135. doi: 10.1007/s10863-0069012-7

Samuels, G. J., Pardo-Schultheiss, R., Hebbar, K. P., Lumsden, R. D., Bastos, C. N., Costa, J. C., et al. (2000). Trichoderma stromaticum sp. nov., a parasite of the cacao witches broom pathogen. Mycol. Res. 104, 760-764. doi: 10.1017/ S0953756299001938

Santos, A., and Marquina, D. (2004). Killer toxin of Pichia membranifaciens and its possible use as a biocontrol agent against grey mould disease of grapevine. Microbiology 150, 2527-2534. doi: 10.1099/mic.0.27071-0

Santos, A., San Mauro, M., Bravo, E., and Marquina, D. (2009). PMKT2, a new killer toxin from Pichia membranifaciens, and its promising biotechnological properties for control of the spoilage yeast Brettanomyces bruxellensis. Microbiology 155, 624-634. doi: 10.1099/mic.0.023663-0

Santos Filho, L. P., Freire, E. S., and Carzola, I. M. (1998). Estimation of cacao production losses caused by witches' broom (Crinipellis perniciosa (Stahel) Singer) in Bahia (in Portuguese). Agrotrópica 10, 127-130.

Saravanakumar, D., Ciavorella, A., Spadaro, D., Garibaldi, A., and Gullino, M. L. (2008). Metschnikowia pulcherrima strain MACH1 outcompetes Botrytis cinerea, Alternaria alternata and Penicillium expansum in apples through iron depletion. Postharvest Biol. Technol. 49, 121-128. doi: 10.1016/j.postharvbio. 2007.11.006

Scarpari, L. M., Meinhardt, L. W., Mazzafera, P., Pomella, A. W., Schiavinato, M. A., Cascardo, J. C., et al. (2005). Biochemical changes during the development of witches' broom: the most important disease of cocoa in Brazil caused by Crinipellis perniciosa. J. Exp. Botany 56, 865-877. doi: 10.1093/jxb/ eri079

Schaffrath, R., and Meinhardt, F. (2005). "Kluyveromyces lactis zymocin and related plasmid-encoded yeast killer toxins," in Microbial Protein Toxins. Topics in Current Genetics, Vol. 11, eds M. J. Schmitt and R. Schaffrath (Berlin: Springer-Verlag), 133-155. doi: 10.1007/b100196

Scherm, B., Ortu, G., Muzzu, A., Budroni, M., Arras, G., and Migheli, Q. (2003). Biocontrol activity of antagonistic yeasts against Penicillium expansum on apple. J. Plant Pathol. 85, 205-213. doi: 10.4454/jpp.v85i3.1032
Schmitt, M. J., and Breinig, F. (2002). The viral killer system in yeast: from molecular biology to application. FEMS Microbiol. Rev. 26, 257-276. doi: 10. 1111/j.1574-6976.2002.tb00614.x

Schmitt, M. J., and Breinig, F. (2006). Yeast viral killer toxins: lethality and selfprotection. Nature Reviews Microbiology 4, 212-221. doi: 10.1038/nrmicrol347

Sharma, R. R., Singh, D., and Singh, R. (2009). Biological control of postharvest diseases of fruits and vegetables by microbial antagonists: a review. Biological Control 50, 205-221. doi: 10.1016/j.biocontrol.2009.05.001

Silveira, R. (2013). Produtores da Bahia serão os primeiros a usar biofungicida Tricovab nas lavouras de cacau. Available at: https://canalrural.uol.com.br/ noticias/produtores-bahia-serao- primeiros-usar-biofungicida-tricovab-naslavouras-cacau-29175/ (Accessed February 14, 2019).

Spadaro, D., and Droby, S. (2016). Development of biocontrol products for postharvest diseases of fruit: the importance of elucidating the mechanisms of action of yeast antagonists. Trends Food Sci. Technol. 47, 39-49. doi: 10.1016/j. tifs.2015.11.003

Spadaro, D., and Gullino, M. L. (2004). State of the art and future prospects of the biological control of postharvest fruit diseases. Int. J. Food Microbiol. 91, 185-194. doi: 10.1016/S0168-1605(03)00380-5

Spotts, R. A., Cervantes, L. A., and Facteau, T. J. (2002). Integrated control of brown rot of sweet cherry fruit with a preharvest fungicide, a postharvest yeast, modified atmosphere packaging, and cold storage temperature. Postharvest Biol. Technol. 24, 251-257. doi: 10.1016/S0925-5214(01)00155-7

Squicciarini, M. P., and Swinnen, J. (2016). The Economics of Chocolate. Oxford: Oxford University Press.

Stenmark, P., and Nordlund, P. (2003). A prokaryotic alternative oxidase present in the bacterium Novosphingobium aromaticivorans. FEBS Lett. 552, 189-192. doi: 10.1016/S0014-5793(03)00920-7

Sui, Y., and Liu, J. (2014). Effect of glucose on thermotolerance and biocontrol efficacy of the antagonistic yeast Pichia guilliermondii. Biol. Control 74, 59-64. doi: 10.1016/j.biocontrol.2014.04.003

Sundh, I., and Melin, P. (2011). Safety and regulation of yeasts used for biocontrol or biopreservation in the food or feed chain. Antonie van Leeuwenhoek 99, 113-119. doi: 10.1007/s10482-010-9528-z

Suzuki, C. (2005). "Acidiphilic structure and killing mechanism of the Pichia farinosa killer toxin SMTK," in Microbial Protein Toxins. Topics in Current Genetics, Vol. 11, eds M. J. Schmitt and R. Schaffrath (Berlin: Springer-Verlag), 189-214. doi: 10.1007/b101843

Suzuki, C., Ando, Y., and Machida, S. (2001). Interaction of SMKT, a killer toxin produced by Pichia farinosa, with the yeast cell membranes. Yeast 18 , 1471-1478. doi: 10.1002/yea.791

Suzzi, G., Romano, P., Ponti, I., and Montuschi, C. (1995). Natural wine yeasts as biocontrol agents. J. Appl. Bacteriol. 78, 304-308. doi: 10.1111/j.1365-2672. 1995.tb05030.x

Syed Ab Rahman, S. F., Singh, E., Pieterse, C. M. J., and Schenk, P. M. (2018). Emerging microbial biocontrol strategies for plant pathogens. Plant Sci. 267, 102-111. doi: 10.1016/j.plantsci.2017.11.012

Taqarort, N., Echairi, A., Chaussod, R., Nouaim, R., Boubaker, H., Benaoumar, A. A., et al. (2008). Screening and identification of epiphytic yeasts with potential for biological control of green mold of citrus fruits. World J. Microbiol. Biotechnol. 24, 3031-3038. doi: 10.1007/s11274-0089849-5

Teixeira, P. J., Thomazella, D. P., and Pereira, G. A. (2015). Time for chocolate: current understanding and new perspectives on cacao witches' broom disease research. PLoS Pathog. 11:e1005130. doi: 10.1371/journal.ppat.10 05130

Teixidó, N., Usall, J., and Viñas, I. (1999). Efficacy of preharvest and postharvest Candida sake biocontrol treatments to prevent blue mould on apples during cold storage. Int. J. Food Microbiol. 50, 203-210. doi: 10.1016/S0168-1605(99) 00105- 1

Thomazella, D. P., Teixeira, P. J., Oliveira, H. C., Saviani, E. E., Rincones, J., Toni, I. M., et al. (2012). The hemibiotrophic cacao pathogen Moniliophthora perniciosa depends on a mitochondrial alternative oxidase for biotrophic development. New Phytol. 194, 1025-1034. doi: 10.1111/j.1469-8137.2012. 04119.x

Tian, S. P., Qin, G. Z., Xu, Y., and Wang, Y. S. (2004). Application of antagonistic yeasts under field conditions and their biocontrol ability against postharvest diseases of sweet cherry. Acta Bot. Sin. 46, 1324-1330. 
Trevizan, S. D. P., and Marques, M. (2002). Social and economic impacts of the cacao crisis: study of a community case (in Portuguese). Agrotrópica 14, $127-136$.

Van Aken, O., Giraud, E., Clifton, R., and Whelan, J. (2009). Alternative oxidase: a target and regulator of stress responses. Physiol. Plan. 137, 354-361. doi: 10.1111/j.1399-3054.2009.01240.x

Vanlerberghe, G. C., Cvetkovska, M., and Wang, J. (2009). Is the maintenance of homeostatic mitochondrial signaling during stress a physiological role for alternative oxidase? Physiol. Plant. 137, 392-406. doi: 10.1111/j.1399-3054. 2009.01254.x

Veiga, A., Arrabaça, J. D., and Loureiro-Dias, M. C. (2003). Cyanide-resistant respiration, a very frequent metabolic pathway in yeasts. FEMS Yeast Res. 3, 239-245. doi: 10.1016/S1567-1356(03)00036-9

Verweij, P. E., Snelders, E., Kema, G. H., Mellado, E., and Melchers, W. J. (2009). Azole resistance in Aspergillus fumigatus: a side-effect of environmental fungicide use? Lancet Infect. Dis. 9, 789-795. doi: 10.1016/S1473-3099(09) 70265-8

Walker, G. M., McLeod, A. H., and Hodgson, V. J. (1995). Interactions between killer yeasts and pathogenic fungi. FEMS Microbiol. Lett. 127, 213-222. doi: 10.1111/j.1574-6968.1995.tb07476.x

Wang, X., Chi, Z., Yue, L., and Li, J. (2007). Purification and characterization of killer toxin from a marine yeast Pichia anomala YF07b against the pathogenic yeast in crab. Curr. Microbiol. 55, 396-401. doi: 10.1007/s00284-007-9010-y

Wang, Y., Yu, T., Xia, J., Yu, D., Wang, J., and Zheng, X. (2010). Biocontrol of postharvest gray mold of cherry tomatoes with the marine yeast Rhodosporidium paludigenum. Biol. Control 53, 178-182. doi: 10.1016/j. biocontrol.2010.01.002

Ward, D. M., Chen, O. S., Li, L., Kaplan, J., Bhuiyan, S. A., Natarajan, S. K., et al. (2018). Altered sterol metabolism in budding yeast affects mitochondrial ironsulfur (Fe-S) cluster synthesis. J. Biol. Chem. 293, 10782-10795. doi: 10.1074/ jbc.RA118.001781

Wei, Y., Mao, S., and Tu, K. (2014). Effect of preharvest spraying Cryptococcus laurentii on postharvest decay and quality of strawberry. Biol. Control 73, 68-74. doi: 10.1016/j.biocontrol.2014.02.016

Weiler, F., and Schmitt, M. J. (2003). Zygocin, a secreted antifungal toxin of the yeast Zygosaccharomyces bailii, and its effect on sensitive fungal cells. FEMS Yeast Res. 3, 69-76. doi: 10.1111/j.1567-1364.2003.tb00140.x

Whaley, S. G., Berkow, E. L., Rybak, J. M., Nishimoto, A. T., Barker, K. S., and Rogers, P. D. (2017). Azole Antifungal Resistance in Candida albicans and Emerging Non-albicans Candida Species. Front. Microbiol. 7:2173. doi: 10.3389/ fmicb.2016.02173

Wickramasuriya, A. M., and Dunwell, J. M. (2018). Cacao biotechnology: current status and future prospects. Plant Biotechnol. J. 16, 4-17. doi: 10.1111/pbi.12848
Wilson, D. (1995). Endophyte: the evolution of a term, and clarification of its use and definition. Oikos 73, 274-276. doi: 10.2307/3545919

Wisniewski, M., Biles, C., Droby, S., McLaughlin, R., Wilson, C., and Chalutz, E. (1991). Mode of action of the postharvest biocontrol yeast, Pichia guilliermondii. I. Characterization of attachment to Botrytis cinerea. Physiol. Mol. Plant Pathol. 39, 245-258. doi: 10.1016/0885-5765(91)90033-E

Wisniewski, M., Droby, S., Norelli, J., Liu, J., and Schena, L. (2016). Alternative management technologies for postharvest disease control: the journey from simplicity to complexity. Postharvest Biol. Technol. 122, 3-10. doi: 10.1016/j. postharvbio.2016.05.012

Yang, C., Hamel, C., Vujanovic, V., and Gan, Y. (2011). Fungicide: modes of action and possible impact on nontarget microorganisms. ISRN Ecol. 2011:130289. doi: 10.5402/2011/130289

Zhang, D., Spadaro, D., Garibaldi, A., and Gullino, M. L. (2010). Selection and evaluation of new antagonists for their efficacy against postharvest brown rot of peaches. Postharvest Biol. Technol. 55, 174-181. doi: 10.1016/j.postharvbio. 2009.09.007

Zhang, V. Q., Gamarra, S., Garcia-Effron, G., Park, S., Perlin, D. S., and Rao, R. (2010). Requirement for ergosterol in V-ATPase function underlies antifungal activity of azole drugs. PLoS Pathog. 6:e1000939. doi: 10.1371/journal.ppat. 1000939

Zhao, L., Zhang, H., Li, J., Cui, J., Zhang, X., and Ren, X. (2012). Enhancement of Biocontrol Efficacy of Pichia carribbica to postharvest diseases of strawberries by addition of trehalose to the growth medium. Int. J. Mol. Sci. 13, 3916-3932. doi: 10.3390/ijms13033916

Zhao, Y., Tu, K., Shao, X., Jing, W., and Su, Z. (2008). Effects of the yeast Pichia guilliermondii against Rhizopus nigricans on tomato fruit. Postharvest Biol. Technol. 49, 113-120. doi: 10.1016/j.postharvbio.2008.01.001

Zhao, Y., Wang, R., Tu, K., and Liu, K. (2011). Efficacy of preharvest spraying with Pichia guilliermondii on postharvest decay and quality of cherry tomato fruit during storage. Afr. J. Biotechnol. 10, 9613-9622. doi: 10.5897/AJB 11.870

Conflict of Interest Statement: The authors declare that the research was conducted in the absence of any commercial or financial relationships that could be construed as a potential conflict of interest.

Copyright (c) 2019 Ferraz, Cássio and Lucas. This is an open-access article distributed under the terms of the Creative Commons Attribution License (CC BY). The use, distribution or reproduction in other forums is permitted, provided the original author(s) and the copyright owner(s) are credited and that the original publication in this journal is cited, in accordance with accepted academic practice. No use, distribution or reproduction is permitted which does not comply with these terms. 